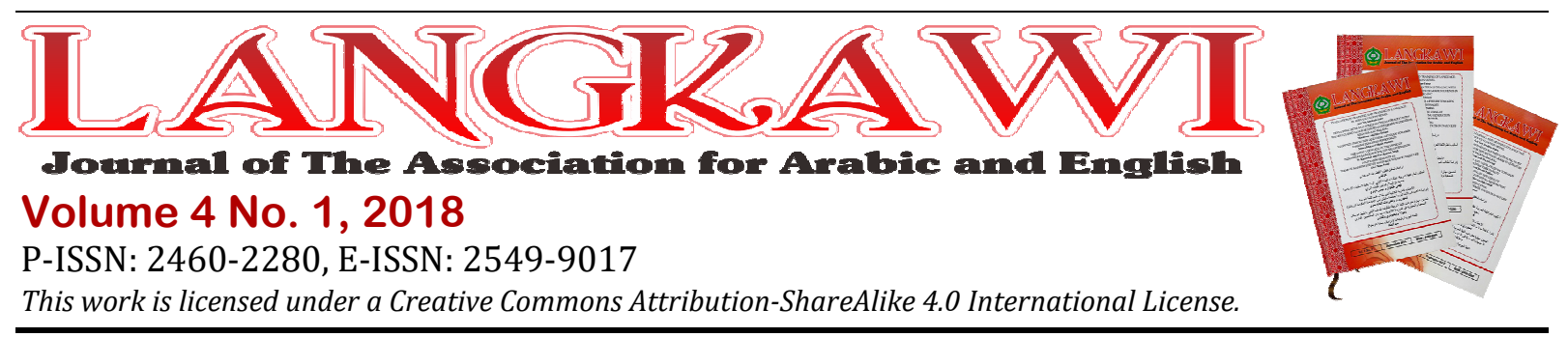

\title{
Mother Tongues Roles' in English Language Learning
}

\author{
Fery Seftiawan ${ }^{1}$
}

1Universitas Negeri Surabaya, Indonesia.E-mail: feryseftiawan16070835026@mhs.unesa.ac.id

\begin{tabular}{l} 
ARTICLE INFO \\
\hline Keywords: \\
Foreign Language; \\
Indonesian Language; \\
Tribal language \\
How to cite: \\
Seftiawan, F., (2018). \\
Mother Tongues Roles' in \\
English Language \\
Learning, 4(1), 1-12. \\
\\
DOI: \\
http://dx.doi.org/10.31332/ \\
lkw.v4i1.747
\end{tabular}

\begin{abstract}
The Indonesian language as the medium of instruction indirectly affects all sectors of life across the nation. Starting from business, workplace, and entertainment to education, Indonesian is used as the main standard language. The usage of Indonesian language leads the hypothesized thought that it may in one side eradicate the existing tribal languages gradually. While on another side it may also have beneficial aspects like helping people (different ethnic group) to communicate as well as assisting remote learners to study English better. Due to the cases happen in two divergent conditions, this paper examines the use of Indonesian language in facilitating learners to study English. The result of this paper shows that Indonesian language implication to some extent helps learners to study English better than those who use tribal language as their daily language to communicate. In term of second language acquisition, the Indonesian language helps learners achieve some words through translation. Children in the different region have different language acquisition as well as their style of learning a foreign language. Those who live in a "sophisticated" area are likely familiar with the Indonesian language that leads them to learn English better than those who live in a suburban area.
\end{abstract}

\section{Introduction}

Indonesia as the second most linguistically diverse country formerly encountered a great language challenge to unite all citizens from any part of Indonesian territories and islands. As the history recalled, the Indonesian language becomes the formal used language which in the past determined to connect all people in Indonesia in term of economic, education, politic, and all aspect of life (Poedjosoedarmo, 2006). What's' more, there are a vast amount of different language users around Indonesia, say for example Java Island, the most populated island which inhabited by various tribes with different language too (Alisyahbana, 1976; Conners \& Klok, 2016). There is Java with its Javanese language, Sunda with Sundanese language, Madura with its Madurese language and many other forms of languages. The fact that Indonesia has approximately existing 700 more languages leads an idea that connecting all people would not be so easy but need to be done to create a link (communication matter) among all people across the nation. As the demand for Indonesian policy, as well as its independence declaration, Indonesian 
language is emphasized to be used and hardly imported to either formal or informal situation (Purwoko, 2011). Therefore, the use of Indonesian language to communicate is extraordinarily vital and importantly considered. By the case of the importance of Indonesian language usage, the issue has arisen in respect to language abandonment.

Setiawan (2013) states that the Javanese language has been started to be left behind in big cities, such as Jakarta and Surabaya. As a consequence, most big cities citizen do not usually use the Javanese language as their daily language. Instead they use Indonesian-Javanese accent language. Furthermore, he claims that at a recent time, Javanese language users are diminishing regarding its speakers (Setiawan, 2013). He moreover ascertains that Javanese language subject will no longer be taught at the level of senior high school, it will only be subjected to the elementary and secondary school level. This fact consolidates the notion that language ignorance is happening years to years. As a consequence, the young Javanese speaker generation will be predicted decreasing by the time and condition factors.

Ghafarpour \& Dabaghi (2016) add that language attrition, a condition where language is no longer used, happens when there are bilingualism and a decreased use of the attiring language (Ghafarpour \& Dabaghi, 2016). Furthermore, language is a social phenomenon which can to some extent evolve ever time considering the environment, i.e. communication technology and attitudes towards language contact, (Dediu, Janssen, \& Moisik, 2016). This explanation draws an argument that language may change due to any situation surrounding. The changing of a particular language leads its user to shift to the more "intelligibly sophisticated" language which suits to the modern era and start to leave their original mother tongues.

The issue arisen above is called linguistic imperialism, a condition where one language dominates other languages in terms of any aspect including cultures (Phillipson, 1992; Pennycook, 1995). This is an important issue since language can be left behind as a result of other modern language's development. In one side, modernization effect prompts civilization development of language changes. Citizen and a certain country will follow the modernized-model era where every aspect is either written or spoken by more "well-known" language. In another side, the "colloquial tribal language" will likely be threatened.

Shifting to the other important factor of existing language in Indonesia, English language is being used and extremely takes an important role too. Most Indonesian students who are learning English multilingual (refer to multilingual learners by (Ortega, 2009:4) which he describes as "two languages which are learned during childhood". Some, but not little of Indonesian language learners have their mother tongue, Indonesian language, and English. Even there are cases that Indonesian students speak three languages at the same time as those who are living in a border of a tribe territory like Javanese-Madurese or Javanese-Banyuwangi language users. They speak two mother tongues in the same moment and they are also required to learn Indonesian language in the school. In addition, they learn to use English too since English is the international foreign language taught in Indonesia. This condition or phenomenon is the example of how Indonesian language learners deal with that language variation that becomes the main concern on this paper. 
The common linguistic problem in big cities is the same that they are reluctant to speak with their own mother tongue i.e. Javanese language. They tend to speak using Indonesian language (Setiawan, 2013) to follow the trend for example. While in another district like suburban area, people are still using their Javanese language as the daily language for communication. Also, in a restricted area where the Indonesian language is rarely used people tend to use pure Javanese language in any form of activity rather than using the Indonesian language.

After considering the Indonesian language as the formal used language in Indonesia, English as the lingua franca and the international spoken language has another side to be criticized. As English is taught as the foreign language (EFL) in Indonesia, there will be such emerging hypothesis that the Indonesian language eases learner to learn a specific language. In case of language learning, the Indonesian language seems to help those who are trying to translate English into the Indonesian language as well as helping learners interpreting the meaning in the target language.

There are previously numerous observed researchers considering the use of L1 language role in learning L2. Like what has been done by Nation (2001) that shows L1 functions as an important role in communicating meaning and content (Nation, 2001). His research deals with speaking and writing aspect, measuring L1 usage to comprehend L2. He concludes that L1 provided the familiar and effective way of getting meaning and content. Another research was also done concerning to the issue of L1 influence on L2. It is about the process of reading which resulted that language transfer in L2 was determined by L1 comprehension (Durgunoglu \& Bhatt, 1992).

The other research states that the L1 helps learners comprehend the sound of L2 (Gong, Cooke, \& Lecumberri, 2015). The author state that the first language determines and facilitates learners to achieve better pronunciation to a target language. Other reported that L1 functions as the bridge or the facilitator to transfer the schema of language (Ionescu, 2014). Also, another aspect of language skills like reading is also influenced by specific language mastery. Kim, et. al (2017) stated that reading comprehension of L2 is shaped by the existing L1. Moreover, the L2 acquisition is fostered by the L1 (Kim, Liu, \& Cao, 2017). Some cases, for example, have been reported that the first or mother tongue has a vital role in either second language learning or acquiring (Artieda, 2017; Denizer, 2017; Derakhshan \& Karimi, 2015).

Considering the issues above, there is a hypothesis of the L1 function over L2. Therefore, in short, the purpose of this paper is to observe the use of mother tongue language in helping students or children to learn the English language. In a nutshell, the proposed idea of the research question is that "what are children L1 roles' in learning English as a foreign language?"

\subsection{Literature Review}

This short related review of literature is provided to help readers to have a clearer and better understanding of this paper. There are several concepts of second language acquisition that are presented here like the concept of language acquisition, EFL in Indonesian context, language monitor and translation, and bilingual and multilingual point of view. They all can be seen in the followings: 


\section{a. The Theory of Language Acquisition}

Language acquisition is a term in which linguists and applied linguists define as "the learning and development of person' language" (Richards \& Schmidt, 2010). Also, the language acquisition is a term derived to explain "the learning and development of a person's language" (Richards \& Schmidt, 2010, p. 312). Language can, in particular, be a first and second or even third in term of an acquisition process. Acquisition happens when someone unconsciously gets any language from any exposure she/he has. Krashen (1982) as the pioneer of language acquisition theory proposed the idea that second or other language acquisition occurs by happenstance. By this idea, it can be concluded that the acquiring process happens at a specific age or time, childhood, adolescence or adulthood (Ortega, 2009).

In terms of acquiring and learning, Ellis (1985) Argued that there is a great differentiation between learning and acquiring a specific language. He states that the term acquisition is different way compared to learning. Acquiring a language means accepting a language through exposure naturally whereas learning refers to a conscious study of a particular language (Krashen, 1982; Ellis, 1985; Yule, 2010). Even those terms are seemingly diverging; they are intertwined and inseparable items. In acquiring a language, learners or in this case children will have, at the same time, learned phonological development, lexis, grammar, and pragmatic knowledge (Ellis, 1985). By learning, children can comprehend, even not many, some new words. Learning a target language may to some degree enable the learner to speak the target language learnt fluently. Another concept is offered by Ellis (1985) is about the leaner's differences in term of acquiring a language. They are aptitude, cognitive style, motivation, and personality. The other related factors which are possibly related to the process of acquiring a language are situational factor, the input, learners' differences, learner's process, and linguistic input. There are numbers of factor influencing the process of language acquisition where one child different from other children. The factors surely influence the process of accepting the language. Moreover, Krashen (1982) mentions numbers of affecting factors in acquiring language pervading aptitude, the role of the first language, routines patterns, individual differences and age. Of those influencing factors, it seems that the role of the first language dominantly affects students or children in accepting a particular language.

\section{b. EFL in Indonesian Context}

Indonesian language functions as the medium of any instruction including in education field, school. The Indonesian language positively affects Indonesian people behaviour within the context of daily activity (refer to the language as an identity shaper) (Ha, 2008:56; Sharifian, 2009:5). English as the international language taught as the foreign language. This condition forces student to study English whatever it takes. The foreign language learning in Indonesia starts from junior high school, but in some cases, English as the foreign language is taught during the elementary school.

\section{c. The Monitor Language Hypothesis}

The important term in learning a target language is a language monitor hypothesis. As Krashen's (1982) statement, language monitor is one of the 
hypotheses in language acquisition which functions to control the language outcome. Whoever say or write in a specific language will employ this term to avoid the incorrectness. The monitor model was originally theorized by Krashen (1982) which proposes that acquisition and learning (a specific language) are two inseparable things. It posits that learning specific language functions as a monitor of acquiring language. This so-called monitor model enables language learners to speak grammatically in accordance with the rule of a specific language. Ellis (1985) in his book states that there are at least five hypotheses of monitor model (Ellis, 1985). They are the acquisition language learning hypothesis, the natural order hypothesis, the monitor hypothesis, the input hypothesis, and the affective filter hypothesis.

By having the language monitor device in the brain, speakers, as well as writers, will be able to control the language output. The language monitors function not only to examine what will be spoken or written, but in some degree, language monitor can also be employed to utter something reversely. In short, language monitors helps people to understand some words before going to say or write. In case of children's experience of learning a new language, this hypothesis is commonly found. Since students will ask for or clarify every new single word, this device will be employed significantly to help learners achieve the unusual new word.

\section{d. Translation Point of View in Learning Foreign Language}

Even translation seems to be a weak method for learning a target language, to some extent in foreign language learning; the interpretation is sufficient enough. As stated by Whyatt (2008) Translation task is crucial since it may help students acquiring and transferring meaning across language barriers (Whyatt, 2008). The translation to some degree may allows learners to cope with the language barriers such as incomprehensible of the definition of a specific language. Moreover, the translation is used to assimilate the L2 through L1.

\section{e. Monolingual and Bilingual Concern}

There are several discussions of the terms monolingual and bilingual study. Rowland (2014) in the book proposed an example of children with the bilingual and monolingual ability. She argued that monolingual children have more advantages than multilingualism (Rowland, 2014). She explained that bilingual or multilingual children tend to be slow to utter the words, while monolingual children are a way around, faster. Furthermore, monolingual children will only focus one language; while bilingual or multilingual will have at the same time more than one language to be concerned. The idea might be correct in that bilingual does not need to think twice in uttering the spoken words or sentences, while bilingual or multilingual must struggle to think before speaking for their "more than one languages" in their mind.

In conclusion, language monitor, translation, and bilingual and multilingual positively related to the children's language development. They are predicted to assist children in getting involved with the new language they encounter. More importantly, those aspects are predicted to be the factors influencing children's language acquisition.

\section{Method}

This paper is qualitative research which focuses on how children with specific languages' skill learn English. As previously discussed above, this paper concerns on 
the comparative aspect of two different English language learners. The children with the different unique background became the subject of this comparative study.

The first student is a Javanese-pure student who speaks Javanese in his daily life to communicate, while the second student is also a Javanese-pure student but having, to some extent, slight understanding about Javanese language and she speaks the Indonesian language as her mother tongue. They are in the same age of 6 and grade but in the different region in East Java. The first student is male and the second is female.

The observation was done using the field-note consisting of two parts named the descriptive and reflective note. The descriptive note was used to describe any surrounding phenomena has something to do with the research, while the reflective was used to express what is researcher's opinion. An observation was conducted during their learning time. Since the researcher as their teacher, it is possible to perform such observation without interfering their learning time. Therefore, this paper seems naturally settled. The teacher' teaching strategy in transferring the target language is grammar translation method. Grammar translation method is used to mediate students to achieve the particular unknown or unusual words. Grammar translation method was chosen because of its simple implementation and its proven goal to language acquisition (Aqel, 2013). It also helps teachers transmitting the target language easily to children in foreign language class than any other strategies.

The materials were about the Basic English vocabularies like the parts of the body, animals, fruits, vegetables, public places, occupation and family member and some functional terms in English.

To complete the overall data, the researcher takes transcription form by Alwright \& Bailey (1991:56-58). It is used to depict the situation during learning times. The transcription is modified into the suited environment of this research to draw the conversation situation during the observation. This transcription was employed to observe the conversation. To fulfil the transcription, the recorder was used.

\begin{tabular}{|ll|}
\hline Symbols & Convention \\
\hline $\mathbf{T}$ & Teacher \\
$\mathbf{S 1}$ & Student, Using Number (s1,s2 and so on) \\
$\mathbf{T}+\mathbf{S S}$ & Teacher and unidentified subgroup \\
[ ] & For comments \\
$\mathbf{X}$ & incomprehensible item, one word \\
$\mathbf{X X}$ & incomprehensible item, phrase length \\
$\mathbf{X X X}$ & incomprehensible item beyond phrase length \\
/ & Pauses \\
Italics & Other languages besides English, and emphasizing words \\
\hline
\end{tabular}

\section{Findings and Discussion}

Based on the aforementioned research question of this paper, this section will illustrate findings of the research. Moreover, there will be some reports to reveal the 
research question of this paper. The field-notes were also taken to draw circumstances during the lesson time. The data were taken during their learning time. It was on every Monday and Wednesday for the first and the second student. Here are the examples of students/children conversation taken during the lesson:

\section{Student 1}

Set one:

Descriptive note: it was Monday, $15^{\text {th }}$ January 2018 when this observation took place. As usual, on every afternoon, the additional English lesson is conducted in one of the respondent's homes of this research.

Teacher: What's this (student 1)? [Mentioning his name] // apa ini ? This is a mosque

Student: ehm, / / oh ini gambar mejid, mas.!

Teacher: mejid? // Masjid ya. In English it is mosque, / ma:sk /

Student: Oh, iya// ma:sk. Masjid.

Teacher: repeat// ulangi setelah saya//. / ma:sk / masjid

Student: / ma:sk / masjid

Reflective note: the conversation above happens in one of the sets in a day. When I was telling him, he was a little bit curious because perhaps there is a certain picture following the English word for a thing.

\section{Set two:}

Descriptive note: it is the following conversation that takes places right after the set above.

Teacher: this is ear. Bahasa Indonesia nya apa ear - / 1 $\mathrm{r}$ ?/ [The teacher holds his ear and shows the picture]

Student: oh tau, tau // kuping ya.!? [He looks sure]

Teacher: almost there, hampir bener. Ayo pakai bahasa Indonesia yang baku

Student: salah?

Teacher: benar, tapi kurang tepat // telinga ya

students: oh iya lupa// telinga.

Teacher: nah,// bagus. Repeat. // coba ulangi

Reflective note: in this part of the conversation, the teacher tried to demonstrate the English word by using a real part of a body. As usual, the teacher tried to evoke student's language awareness by using repetition. 


\section{Set three}

Descriptive note: in the following week, the lesson began as usual. The student was ready to follow the English lesson.

Teacher: Afternoon [greet him]

Student: Afternoon pak

Teacher: let's// we// speak// English. Let's / / we// speak// English.[ the teacher spoke very clamly]

Student: let's go/ /

Teacher: see//. This picture// lagi apa sih mereka ini?

Student: lagi apa ya/ / berdiri?

Teacher: no. please/ / coba lagi

Student: oh. ngomong-ngomong kan

Reflective note:

The piece of conversation above is almost the same in case of students' incorrectness of using a more Indonesian standardized language.

In different cases, here are the transcriptions of the second respondent:

\section{Student 2}

Set one:

Descriptive note: It was $24^{\text {th }}$ January 2018 . The day of the second children occasionally learns an additional English lesson for preparing the next level of the schooling system, elementary school.

Teacher: come on guess what I have for you. What is this? This is cabbage, /kæb.Id3/

Student: oh oke, kæb.Id3. / / kol, kubis / / [quite sure about her answer]

Teacher: well done, you are right, bener / / and this one is? [The teacher hides the picture of elbow and knee]

Student: I tau itu, lutut and siku, [laughing]

Teacher: Kebalik, ya .

Reflective note: the treatment of both students is the same. With pictures some time, and without any of those. 


\section{Set two}

Descriptive note: it was the following week that this conversation was done. The student was ready to learn English.

Teacher: how / / are// you//? [mentioning her name]

Student: I am fine [her answer was not too correctly pronounced]

Teacher: Where is mama?

Student: ma,// ma [the student understand what teacher said. It is indicated by her action to call her mum when she was asked]

Teacher: oh oke, thank / / you.

Student: iya.

Teacher: Jadi, apa itu /wer/. Where?

Student: kemana?

Reflective note: the teacher tried to ignite student's awareness by using the surrounding. Her mum was called by her once the teacher asked her where.

The additional research data collection was the unstructured interview. The researcher interviewed their mother. In case of the first student, his son is not accustomed to any of English TV program. Moreover, he uses the Javanese language during his daily live. In the other case, the second student, even not occasionally, watches the English TV program like ruby the rabbit, toopy and binoo, and others.

The bold words are several examples existed in the students' text book with pictures. However, at the end of the chapter, there will be picture abolishment. They are the example of how students' language is formed and affected by their surroundings.

\subsection{Discussion}

There are some cases of language understandable as well as incomprehensible at the same time during the observation. The first student/child who speaks the Javanese language has such difficulties in learning English. He needs to understand the Indonesian-translation version first before going to the Javanese translation (see set one and two). He struggles to interpret English to Javanese, while at the same time he also tried hard to think about the Indonesian language. This is in line with what expressed by Rowland (2014:197-198). However, in one case, a student with bilingual and multilingual language ability tend to do the more complicated cognitive task. Different language environment makes them sometimes unable to utter words correctly.

The other case of the second student who speaks Indonesian was different. The second student even did not understand the basic word of English was able to get the intended meaning of a specific word without any (Indonesian) translation. The significance influence of Indonesian language over English is better in this second subject. It has something to do with the literacy activity in her home that leads her perform better. Watching Television, and using first (Indonesian language) 
are some supporting factors of English language learning. It supported by Artieda (2017) that first language literacy affects second language in certain parts of skill.

The first child to some extent tried to ask for the Indonesian translation or Javanese translation first of English words. He sometimes asks what the meaning of this thing is. How do we use it? while the second student did not perform the same curious question. The word mosque for instance; it was not properly translated by the first children (students). The first student will say mosque as langgar or mejid (Javanese language of mosque) rather than saying masjid (formal Indonesian language of mosque). This is in line with the research found by Gong, Cooke, \& Lecumberri (2015) that first language dominantly roles in second language input.

The other word like cabbage was also translated differently by the first student; he translated cabbage as gubis (Javanese) instead of kubis (Indonesian version of cabbage). The word speak was translated ngomong (Indonesian slank language and Javanese language too), while the exact translation is bicara. In short, it can be concluded that the translation was influenced by the surrounding activities which affect students' language. This is supported by the Derakhshan \& Karimi, (2015) and Denizer, (2017) that first language can be a good interference in language acquisition.

The other interesting case was the students' lack of translating an English word into Indonesian. For example, the first student could not translate (word without any pictures) from English to Indonesian language. The word knee could not easily translate to Indonesian. He did not understand the word lutut (Indonesian translation of knee) as a consequence there was "double translations" from English to Indonesian to Javanese language at the same time. The other word like ear was not understood by him too. In respect with that case, the teacher needs to translate ear to telinga (Indonesian) to kuping (Javanese intelligible word for student that is raised (borrowed) to be one of formal Indonesian languages i.e. jamur kuping). This can be a contributor matter that the vocabularies acquisition of a target language is highly determined by the mother tongue (Khan, 2016). The case of the other student was quietly different. The second student was directly translating the word accompanied by pictures easily. There was no significant difficulty during the process of learning English.

While in the word without any pictures, the second student tried to engage her with teacher's attitude toward the word (teacher demonstrate and hint the words). She eventually did a good job in translating the words with or without any pictures. However, there are some languages unintelligible during the process because of some unusual or rarely-used words.

Of the prominent factors influencing the outcome standard language used by children, parental engagement is neglected. Their role in shaping students' language is vital in a way that by them children firstly imitates and learns.

\section{Conclusion}

Based on the elaborative paragraphs, it can, to some extent, be concluded that first language or mother tongue may help or even became a barrier to learn a specific language such as learning English. In specific, the daily language usage determines the way people (children) react to other kinds of communicative manner, i.e. speaking and writing. 
The idea of monolingual outperformed bilingual children has been proved that in some context the monolingual children may have a better understanding about a specific language than bilingual children. Also, like the review of the literature, monolingual children are easy and much better to retention a new language as well as its grammatical function than those of bilingual children.

Regarding Indonesian language deficient, several components of government, society and community are having serious issues to be concerned about. The big job for them is to facilitate the wider chance for an educator to bring learners into Indonesian language usage. Furthermore, what may help learners have better understanding toward Indonesian is that the exposure or their milieu. School or institution, TV, home literacy are some common situations that can help children with lack of Indonesian language to have a better sight of it.

However, it is not fair to abandon tribal language for mastering the Indonesian language as well. Therefore, it is the job for the government too to provide a suitable environment to have either studying tribal or Indonesian language as well as adding the international language learning at the same time.

Like the fact that English is being taught for young learners, there is such strong advice that it will not be truly effective. English for young learners is not adequately suitable for those (children) who stay in restricted area where Indonesian language is rarely employed in daily communication. The authority board of English learning for children should be aware of this condition that children in cities are completely different from children in rural or village area. As a consequence, it is suggested that English learning for children in such a rural area need to be reconstructed and evaluated.

Moreover, gender, as well as language proficiency, should perhaps be included in the further research to reveal deeper the relationship between first language and foreign language learning.

\section{References}

Aqel, I. M. (2013). The Effect of Using Grammar Translation Method on Acquiring English as A Foreign Language. International Journal of Asian Social Science, 22265139.

Artieda, G. (2017). The role of L1 literacy and reading habits on the L2 achievement of adult learners of English as a foreign language. System, 168-176.

Cenoz, J. (2011). The Influence on Bilingualism on Multilingualism Acquisition: Some Data From The Bosque Country.

Dediu, D., Janssen, R., \& Moisik, S. R. (2016). Language is not isolated from its wider environment: Vocal tract influences on the evolution of speech and language. Language and Communication Journal, 1-12.

Denizer, E. N. (2017). Does Mother Tongue Interfere in Second Language Learning? Journal of Foreign Language Education and Technology.

Derakhshan, A., \& Karimi, E. (2015). The Interference of First Language and Second Language Acquisition. Theory and Practice in Language Studies, 2112-2117. 
Durgunoglu, \& Bhatt, H. (1992). The Role of First Language in the Second Language Reading process. Illinois: the University of Illinois at Urbana-Champaign.

Ellis, R. (1985). Understanding Second Language Acquisition. Oxford: Oxford University Press.

Ghafarpour, H., \& Dabaghi, A. (2016). Cross-linguistic influence of the second language on the first Written production of Iranian immigrants to Australia. Elsevier.

Gong, J., Cooke, M., \& Lecumberri, M. L. (2015). A quantitative model of first language influence in second language consonant learning. Elsevier, 17-30.

Gong, J., Cooke, M., \& Lecumberri, M. L. (2015). A quantitative model of first language influence in second language consonant learning. Speech Communication, 17-30.

Ionescu, D. I. (2014). An Analysis of The Role of First Language in Second Language Acquisition. San Diego.

Jessner, U. (2008). Teaching Third Language: Findings, Trends, and Challenges. Austria: Cambridge University Press.

Khan, M. S. (2016). The Impact of Native Language Use on Second Language Vocabulary Learning by Saudi EFL Students. English Language Teaching.

Kim, S. Y., Liu, L., \& Cao, F. (2017). How does first language (L1) influence second language (L2) reading in the brain? Evidence from Korean-English and Chinese-English bilinguals. Elsevier, 1-13.

Krashen, S. D. (1982). Principles and Practice in Language Acquisition. California: Pergamon Press Inc.

Nation, P. (2001). The role of the first language in foreign language learning. ASIAN EFL JOURNAL.

Ortega, L. (2009). Understanding Second Language Acquisition. New York: Routledge.

Purwoko, H. (2011). If Javanese is Endangered, How Should We Maintain It? International Seminar "Language Maintenance and Shift. Semarang: Diponegoro University.

Richards, C. J., \& Schmidt, R. (2010). Longman Dictionary of Language Teaching and Applied Linguistics Fourth Edition. Edinburg: Pearson.

Rowland, C. (2014). Child Language Acquisition. Newyork and London: Routledge.

Setiawan, S. (2013). Children Language in Bilingual Community in East Java. The University of Western Australia, School of Humanities.

Whyatt, B. (2008). Bilingual Knowledge And Interlingual skill: A Discussion of The Benefit of Translation Task for Second Language Learners. In M. Pawlak, Investigating English Learning and Teaching (p. 199). Poznań: EXPOL.

Yule, G. (2010). The study of language (fourth edition). UK: Cambridge University Press. 